\title{
Effects of Generational Competition and Substitution on Late Labour Participation and Labour Market Exit from a Multilevel Perspective $^{*}$
}

\author{
Henriette Engelhardt, Christopher Schmidt
}

\begin{abstract}
In this paper, we investigate the effects of demographic, economic and labour market structures on labour market participation and on the transition to inactivity (exit) for older males in eleven European countries. Theoretically, our analysis is guided by considerations of intragenerational competition and intergenerational substitution. Following Easterlin's hypothesis that intragenerational competition rises with cohort size, we assume a negative effect of cohort size on labour market participation and a positive effect on early exit from the labour market. Taking into account that different cohorts are substitutes at least to a certain extent, we assume that the probability of an early exit will be reduced by a high intergenerational exchange ratio in favour of older workers. Thus, labour market participation is influenced by the populations' age structure both when entering the labour force and during the career. Moreover, low shares of graduates in older cohorts are expected to reduce older workers' chances of labour market participation. In addition to demographic structures, general economic conditions, such as per capita GDP and its development over time, act both to further and to hamper the employment of older workers. Additionally, labour market structures, such as unemployment rates, the extent of part-time work or the amount of service jobs influence individual participation and the transition to inactivity. To test these hypotheses, we use merged data from the first two waves of SHARE and macro-level indicators from Eurostat. We estimate a two-level random-intercept logit model which allows us to determine the share of variance in international late careers that can be attributed to countryspecific factors and can quantify the relative impact of specific socio-demographic and socio-economic backgrounds. Our results imply that cross-national variance in labour market participation is mainly driven by the instance of long-term unemployment and the share of highly-educated older men. While our analyses reveal some evidence of intragenerational competition, we do not find evidence of intergenerational competition forcing early exit or decreasing participation.
\end{abstract}

See Engelhardt and Schmidt (2011) for an earlier version of this paper. 
Keywords: Older workers - Labour market participation - Early labour market exit · Relative cohort size $\cdot$ Multi-level modelling $\cdot$ Retirement

\section{Introduction}

European labour markets are characterised by high rates of unemployment among older workers and early retirement. Sustained demographic change in Europe is however calling for "unused capacity" to engage in active work (Börsch-Supan et al. 2009). Therefore, many countries have introduced institutional reforms, such as by increasing the mandatory retirement age, in order to increase the labour supply among the aged (Eichhorst 2011). Although the labour force participation of older workers has increased in most European countries over the last years, the shares of older men who are employed or have at least not retired differ markedly across Europe (Fig. 1). Participation rates vary from 85 percent in Switzerland and 82 percent in Sweden, to 60 percent in Belgium and France in 2009. Employment rates vary to a somewhat greater extent between countries and over time, but reveal mainly similar patterns.

From a theoretical point of view, numerous determinants are linked to crossnational variance in labour force participation rates. Demand-side driven arguments consider participation rates as a result of economic constraints depending on business cycles (Auer/Fortuny 2000; Dorn/Souza-Posa 2010). Supply-side oriented literature focuses on the individual choice to withdraw from the labour market. Individual decisions in this framework are made on the basis of individual and institutional factors (Buchholz et al. 2006; Hofäcker 2010; Engelhardt 2011). On the aggregated level, these individual choices add up to different participation rates across countries.

By focussing on institutional settings and statutory provisions, structural effects are mostly disregarded in explaining internationally varying labour force participation. Different age structures and cohorts' educational attainment influence labour participation in addition to labour market structures and economic conditions (Bloom et al. 1987; Garloff et al. 2010; Stenberg/Wikström 2004; Zimmermann 1991). Our analysis tries to shed some light on the potential effects exerted by different factors on labour market participation and exit, other than institutional arrangements such as the statutory retirement age or employment protection. So we entirely exclude institutions and financial incentives from our analysis. Nevertheless, we appreciate that institutional arrangements are crucial to internationally varying career patterns. Our key hypothesis, however, says that there are yet other national characteristics which correlate with labour market participation and exit. Based on this hypothesis, we try to figure out which country characteristics offer the greatest potential when it comes to explaining national-level variance.

Ideas on the possible effects of the population's age structure on individual careers go back to Easterlin's hypothesis, which suggests that the relative size of a cohort is positively associated with the level of intragenerational competition (East- 
Fig. 1: Labour force participation and employment rates of males aged 50 to 64, 1983-2009
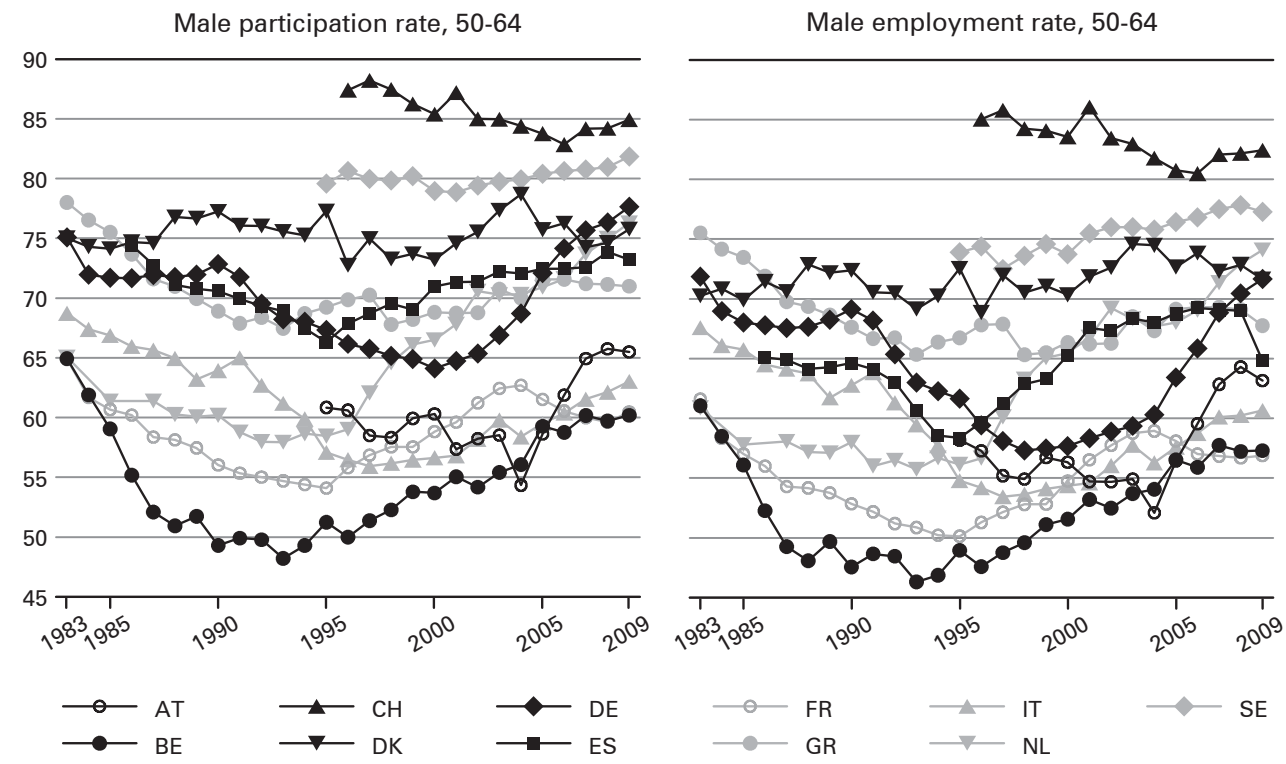

Source: Eurostat Online Database (2010), selected countries

erlin 1980). Rising competition operates as a relative disadvantage for members of large birth cohorts when they enter the labour market and finally results in lower participation rates. This relationship should additionally be shaped by cohort succession: The size of younger cohorts should be negatively related to the labour force participation of older workers as they might be substituted (Macunovich 2009). Drawing on these ideas, we assume that demographic and socio-economic structures influence current labour force participation and transitions to retirement. They act as starting conditions in times of labour market entry and as current conditions due to changes throughout careers. In particular, we analyse the effects of age distributions, educational compositions as well as of labour market and economic conditions on late careers in Europe using data from the first two waves of the Survey of Health, Ageing and Retirement in Europe (SHARE), complemented by aggregate data from Eurostat. Our empirical framework is based on comparing a single cohort across different countries. Therefore, variance is country specific and not cohort specific, and Age-Period Cohort interdependence does not need to be disentangled.

In the following section, we discuss theoretical effects of demographic, economic, and labour market structures on micro-level behaviour; in addition, this section provides related work from the literature. The subsequent section contains descriptions of the data, variables and methods we used. In the fourth section, we present and interpret the results of our empirical analysis. The paper concludes with a sum- 
mary and an outlook on further research which may deepen the understanding of the relationship between social structure and individual behaviour.

\section{Theoretical framework}

\section{Effects of demographic, economic and labour market structures on late careers}

It is well-established that labour force participation and transitions to retirement vary with country-specific characteristics, in particular with countries' economic and institutional features, such as business cycles (e.g. Bils 1985; Bosworth/Burtless 2010; Bover et al. 2002; Darby et al. 2001; Dereveux 2000; Elsby et al. 2010), pension systems and welfare arrangements (e.g. Debrand/Sirven 2009; Börsch-Supan et al. 2009; Engelhardt 2011), employment relation systems, educational systems and employment-sustaining active labour market policies (e.g. Eichhorst 2006; Buchholz et al. 2006; Hofäcker 2010; Engelhardt 2011). Less attention has been paid to the international variance of late careers by demographic, labour market and long-term economic structures.

As Easterlin (1980: 29-34) pointed out, relative cohort size affects individual chances throughout the whole lifecycle. Belonging to a comparatively large birth cohort negatively influences one's chance of successfully entering the labour market as well as the chance to remain in it. Easterlin argues that rising relative cohort size leads to greater competition within a cohort. Consequently, members of large cohorts share a higher risk of unemployment when they enter the labour market (Bloom et al. 1987). This effect is also called "cohort crowding", and mainly refers to consequences for educational attainment, unemployment and wages at the beginning of working life (e.g. Bound/Turner 2007; Keister/Deeb-Sossa 2001; Korenman/ Neumark 2000; Welch 1979). In line with Easterlin, we assume that this effect of intragenerational competition lasts over the whole career. Thus, relative cohort size when entering the labour market has a negative impact on labour force participation rates in older ages. Therefore, cross-national variance in labour force participation and exit should be explained - at least to some extent - by different relative cohort sizes.

Moreover, there is some empirical evidence suggesting that the older generation is crowded out by the younger generation: Performing time-series analysis with co-integration techniques on age-specific unemployment rates from 1967 to 1988 , Zimmermann (1991) finds a positive impact of relative cohort size (number of 15 to 34 year olds divided by the number of 35 to 54 year olds) and relative cohort age (the mean age of young cohort divided by the mean age of old cohort) on unemployment of the older generation both in the short and in the long run for Western Germany. Analysing cross-state differences in the United States from 1978 to 1996, Shimer (2001) uncovers a negative effect of the youth share within the working-age population (number of 16 to 24 year olds divided by the number of 16 to 64 year olds) on age-specific unemployment and a positive effect on age-specific participa- 
tion and employment rates. Shimer's theoretical argument for this quite surprising effect on unemployment is based on young workers creating fluid labour markets due to increased mobility and thereby stimulating vacancy creation. This argument however does not go far enough towards explaining cross-national differences in labour force participation and retirement. We assume that countries with a high prevalence of on-the-job training and less institutionalised careers produce higher rates of turnover of workers. Following Shimer, more jobs should be offered in local labour markets with an above-average percentage of young employees which eases labour force participation and labour maintenance of the aged. On national level, though, we suppose intergenerational competition to be the driving force. If large cohorts enter the labour market, competition increases between cohorts and labour force participation by the elderly should shrink, whereas exit rates should rise.

The correlation between the relative cohort size of the young and the labour force participation by the aged only holds true under the assumption that younger and older workers can substitute one another at least to some extent. For so called "bridge jobs" (Ruhm 1990), which are predominantly widespread in the United States, this assumption is well established (e.g. Macunovic 2009). However, there is little or no evidence that younger and older workers are completely interchangeable (Card/Lemieux 2001; Hamermesh 1993; Ka/wij et al. 2009). They differ concerning their skill levels as job requirements and occupational structure altered from cohort to cohort in line with technological change (Acemoglu 2002; Blossfeld 1987, 1989; DiPrete et al. 1997). Therefore, different education and training of young and old workers stands in the way of their interchangeability. They may therefore only be substitutes for unskilled jobs. Assuming this to be the case, an increasing share of the highly qualified among the aged (i.e. with tertiary education) should result in an enhanced probability of labour force participation for workers of all educational levels among the elderly.

This macro-micro relationship differs from the individual-level effect of education, which states that high educational attainment correlates with a lower risk of unemployment and better chances of (re)employment (Buchholz et al. 2006; Chan/ Stevens 2001; Hairault et al. 2010). If older workers only compete with younger ones for unskilled jobs, older workers with a tertiary education are out of the contest. Assuming a constant supply of low-skilled jobs, a large share of older workers with high levels of education will then reduce the competition. A limited number of competitors increase the individual probability of being hired for less skilled older workers.

Next to age structure and cohorts' educational attainment, current labour market conditions influence participation and exit rates. Reduced working hours at higher ages are considered as an instrument to postpone the age of retirement and therefore enhance labour force participation among the elderly (Bosch/Schief 2007; De/sen 1996). The availability of part-time jobs for older workers should affect individual labour force participation positively and accordingly also the transition to inactivity negatively. Additionally, employment in the service sector is also regarded as a factor which enhances chances of late employment because of less economic restructuring due to globalisation in this sector (Blossfeld et al. 2006). Hence, we assume 
that the share of older employees working in service jobs is positively correlated with the probability of labour force participation and negatively with labour market exits.

Unemployment is another important aspect of the current labour market situation. In some countries, such as Germany, long-term unemployment is widespread among the aged (OECD 2005), and unemployment is often used as a pathway into retirement (Brussig/Wübbecke 2009). Thus, higher levels of long-term unemployment of older people indicate poor employment opportunities as well as a prevalent bridge strategy, leading to different effects on individual labour force participation. On the one hand, we expect a negative effect of long-term unemployment, if unemployment is completely involuntary and exits into retirement are realised as soon as possible. On the other hand, we assume a non-negative effect on individual labour force participation if as long-term unemployment is at least to some extent voluntary and provides a commonly used pathway into retirement. Therefore, long-term unemployment should not be correlated with an increased risk of exit or the chance of labour force participation.

All socio-demographic and labour market-related factors discussed so far result in an oversupply of labour. Mainly economic research shows that business cycles influence job opportunities by shaping the demand for labour. According to Okun's law, there is a negative relationship between unemployment and economic strength (Lee 2000; Okun 1962). Economic expansion affects the timing of retirement through two channels: firstly, a healthier job market and, secondly, gains in individual wealth. The two phenomena have opposite effects. In a stronger economy, employers hire more actively and there are fewer redundancies, so that people retire later than they otherwise might. Prosperity increases the individual resources for realising a preference for leisure and leaving the workforce. Economic recession affects the timing of retirement in both channels in the opposite direction (Bosworth/Burtless 2010).

Albeit most research deals with the short-term consequences of economic development (e.g. Bils 1985; Bosworth/Burtless 2010; Bover et al. 2002; Darby et al. 2001; Dereveux 2000; Elsby et al. 2010), recent empirical studies reveal evidence that the economic conditions prevailing at the time of entering the labour market influence not only initial job opportunities and wages, but also late careers (e.g. Brunner/Kuhn 2010; Kahn 2010; Kwon et al. 2010; Oreopoulos et al. 2008). In accordance with Easterlin's hypothesis on relative cohort size, economic conditions at labour market entry are assumed to shape future opportunities. Episodes of booms or busts facilitate recruitment of staff respectively necessitate redundancy. Therefore, the careers of young workers might be tracked through a demand surplus, or conversely a deficit (Brunner/Kuhn 2010). Per capita GDP at labour market entry should therefore explain country-specific variance, and it should be negatively related to labour market exits. 


\section{Effects of the work context and individual characteristics on late careers}

Country-level variance is reflected in individual-level as well as occupational or industrial-level variance (Engelhardt 2011). Therefore, we have to control for individual characteristics and the work context in order to estimate the labour force participation and early exits of older employees.

Far-reaching changes in the labour market due to globalisation and the "crisis of mass production" (Castells 2000) encourage firms to react by readjusting staff levels. Especially classical industries like manufacturing are hit by a need for restructuring as they shrink all over Europe. Older employees in such sectors should show a higher probability of entering early retirement than employees in growing economic sectors such as the service sector (Buchholz et al. 2006). Even firm size affects the probability of retirement positively. Economic changes force larger firms to adjust their organisational structures via downsizing and outsourcing (Hofäcker 2010). These measures of reorganisation particularly affect older employees. Their wages are often higher due to deferred compensation and seniority wages (Hutchens 1986; Lazear 1979) and the returns of training are smaller due to shorter periods of employment remaining (Prskawetz/Lindh 2006). Additionally, larger firms are better placed to offer early retirement incentives. Occupational pension schemes and severance payments add up to "offers that one does not refuse" (Bellmann/Janik 2007). Under these circumstances, the probability of early retirement is assumed to be higher in large firms (Buchholz et al. 2006).

Given that occupational structure changes and whole industries can go into decline, human capital, occupation and qualification become pivotal for late careers. High qualification protects people from several labour market risks (Blossfeld et al. 2006). A low level of education should generally reduce labour force participation and increase the risk of early retirement.

In addition to these "push factors" (Schils 2008) of employment, labour force status itself is important. Self-employment implies individual pension plans and a high commitment to work. Early retirement is often impossible or at least not wanted for these reasons. Self-employment decreases the probability to retire early (B/öndal/ Scarpetta 1998). Moreover, empirical work shows that good health and especially the absence of severe disability increase the probability to participate in the labour market (Currie/Madrian 1999; Börsch-Supan et al. 2009).

Finally, determinants of household composition and characteristics of the partner need to be considered. Labour force participation and labour market exit depend on the number of household members and the employment status of a potential partner.

Drobnič (2002) for example studied "coupled retirement", and concluded that individual retirement transitions are timed with the spouse. Therefore, a spouse who is still working might reduce the probability to exit the labour market early. Household size may be decisive, as large households tend to have more problems to retain their standard of living with pensions that are lower than wages (B/öndal/ Scarpetta 1998). 


\section{Data and Methods}

\section{Individual data}

Our empirical analysis is based on the first two waves of the Survey of Health, Ageing, and Retirement in Europe (SHARE), which collects individual data on employment, health and various socio-economic variables for persons aged $50+$ across 14 European countries (Börsch-Supan/Jürges 2005). ${ }^{1}$ The data from eleven countries that participated in both waves (Austria, Belgium, Denmark, France, Germany, Greece, Italy, the Netherlands, Spain, Sweden and Switzerland) permit the identification of labour force participation in 2004, transitions from work to inactivity (exit) between 2004 and 2006, and the individual factors motivating these transitions (cf. Engelhardt 2011).

For our analyses of labour force participation we restrict our sample to individuals aged 50 to 64 at the time of the first wave and estimate the probability of being a member of the labour force (being employed, self-employed or unemployed) in 2004. For the analysis of transition to inactivity (synonymic labour market exit), we focus on persons who were 50 to 61 years old and had been members of the labour force in 2004, and estimate their probability to leave the labour force (as retired, permanently sick, disabled or homemaker) before the second wave. Instead of looking at potentially temporary job losses, this analysis allows to investigate whether individuals effectively withdraw from the labour force. The age range ensures not including persons being 65 years old at the second wave (which is the mandatory retirement age in most SHARE countries, cf. Engelhardt 2011).

As the eleven countries show very different labour force participation rates for older women, creating sample-size problems in conservative and in Southern European countries, we restrict our analysis to male late-career patterns. The selected sample restricts the analyses of labour participation to 4,557 and the analyses of transition to inactivity to 2,739 observations. The number of cases is further reduced in the multivariate analyses due to missing observations on relevant covariates (Engelhardt 2011).

As control variables we include a set of individual and household characteristics both in the labour force participation and the labour market exit model (cf. Engelhar$d t$ 2011). As individual characteristics we include dummy variables for age (threeyear intervals), subjective health (less than good health) and highest educational

1 This paper uses data from SHARELIFE release 1, as of November $24^{\text {th }} 2010$ or SHARE release 2.5.0, as of May 24th 2011. The SHARE data collection has been primarily funded by the European Commission through the $5^{\text {th }}$ framework programme (project QLK6-CT-200100360 in the thematic programme Quality of Life), through the 6 th framework programme (projects SHARE-I3, RII-CT- 2006-062193, COMPARE, CIT5-CT-2005-028857, and SHARELIFE, CIT4-CT-2006-028812) and through the $7^{\text {th }}$ framework programme (SHARE-PREP, 211909 and SHARE-LEAP, 227822). Additional funding from the U.S. National Institute on Aging (U01 AG09740-13S2, P01 AG005842, P01 AG08291, P30 AG12815, Y1-AG-4553-01 and OGHA 04-064, IAG BSR06-11, R21 AG025169) as well as from various national sources is gratefully acknowledged (see http://www.share-project.org for a full list of funding institutions). 
Tab. 1: Means of variables used in the analysis of labour force participation and labour market exit

\begin{tabular}{|c|c|c|c|c|c|c|}
\hline & \multicolumn{3}{|c|}{ Labour force participation } & \multicolumn{3}{|c|}{ Labour market exit } \\
\hline & Participants & $\begin{array}{l}\text { Non } \\
\text { participants }\end{array}$ & Total & $\begin{array}{l}\text { In the } \\
\text { labour } \\
\text { market }\end{array}$ & $\begin{array}{c}\text { Out of } \\
\text { the labour } \\
\text { market }\end{array}$ & Total \\
\hline \multicolumn{7}{|l|}{ Individual characteristics } \\
\hline Age $50-52$ & 0.268 & $0.048 * * *$ & 0.193 & 0.333 & $0.085^{* * *}$ & 0.293 \\
\hline Age 53-55 & 0.267 & $0.082 * * *$ & 0.204 & 0.309 & $0.209 * * *$ & 0.293 \\
\hline Age 56-58 & 0.234 & $0.183^{* * *}$ & 0.217 & 0.240 & $0.338 * * *$ & 0.256 \\
\hline Age $59-61$ & 0.147 & $0.302^{* * *}$ & 0.199 & 0.119 & $0.368 * * *$ & 0.159 \\
\hline Age 62-64 & 0.084 & $0.386 * * *$ & 0.187 & & & \\
\hline Primary education & 0.332 & $0.460 * * *$ & 0.375 & 0.316 & $0.368^{*}$ & 0.324 \\
\hline Secondary education & 0.375 & $0.336^{* *}$ & 0.362 & 0.383 & 0.372 & 0.381 \\
\hline Tertiary education & 0.293 & $0.205^{* * *}$ & 0.263 & 0.301 & $0.260+$ & 0.294 \\
\hline Less than good health & 0.126 & $0.297 * * *$ & 0.184 & 0.114 & $0.200 * * *$ & 0.128 \\
\hline \multicolumn{7}{|l|}{ Household characteristics } \\
\hline Log (HH gross income) & 10.694 & $10.280 * * *$ & 10.553 & 10.727 & $10.572^{* *}$ & 10.702 \\
\hline Log (household size) & 0.877 & $0.771 * * *$ & 0.840 & 0.906 & $0.829 * * *$ & 0.894 \\
\hline Partner employed & 0.473 & $0.066 * * *$ & 0.334 & 0.499 & $0.405^{* * *}$ & 0.484 \\
\hline No partner & 0.144 & 0.149 & 0.146 & 0.148 & $0.110^{*}$ & 0.142 \\
\hline \multicolumn{7}{|l|}{ Characteristics of (last) job } \\
\hline Self-employed & & & & 0.223 & $0.115^{* * *}$ & 0.206 \\
\hline Unemployed & & & & 0.071 & $0.170 * * *$ & 0.087 \\
\hline Tertiary sector & & & & 0.549 & 0.524 & 0.545 \\
\hline Public sector & & & & 0.279 & 0.310 & 0.284 \\
\hline 1-24 employees & & & & 0.560 & 0.554 & 0.559 \\
\hline 25-199 employees & & & & 0.272 & 0.251 & 0.269 \\
\hline $200+$ employees & & & & 0.168 & 0.195 & 0.173 \\
\hline Satisfied with job & & & & 0.863 & $0.740 * * *$ & 0.843 \\
\hline Observations & 2,961 & 1,532 & 4,493 & 2,265 & 435 & 2,700 \\
\hline
\end{tabular}

Notes: Means and observations refer to the full model where all observations with missing values are dropped; differences between the two groups significant at $+p<0.10$, $* \mathrm{p}<0.05, * * \mathrm{p}<0.01, * * * \mathrm{p}<0.001$

Source: SHARE, Version 2.5.0; own calculations

level (primary, secondary, tertiary level). The means of these variables are displayed in Table 1.

As household characteristics we include imputed total gross household income divided by purchasing power parity (i.e. nominal gross income) in logarithms, which is especially appropriate for comparisons of countries with different levels 
of income. ${ }^{2}$ To avoid assumptions about an equivalence scale, we follow Schwarze (2003) by additionally considering household size in logarithms. Moreover, the presence of a partner in the household and her employment are captured with two dummy variables.

In the analyses of transition to inactivity, we additionally control for job characteristics. Information on the size of the firm is classified $(200+$ employees, 25 199 employees, fewer than 25 employees). To account for the fact that firm size has only been collected for private sector employees, we additionally introduce a dummy variable differentiating between public and private sector as well as selfemployment. Moreover, we control for the sector (tertiary, non-tertiary) and for job satisfaction.

\section{Aggregate data}

Macro-level data on demographic structures as well as the economic and labour market structures are taken from Eurostat and refer to the time of the first wave of SHARE, if not stated otherwise. Figure 2 provides an overview of the relationship between the socio-economic variables and the labour force participation rate of men aged 50 to 64 for the SHARE countries in 2004 on the macro level.

The indicator for testing Easterlin's hypothesis on the relative cohort size is the share of men aged 15 to 29 years within all males aged 15 to 64 years in 1970 . We refer to 1970 because 50 to 64 year old men in 2004 are aged 15 to 29 years in 1970 . Figure 2 (first graph, top left) shows a weak correlation between the share of young men in 1970 and the labour force participation of men aged 50 to 64 in 2004. Contrary to Easterlin's hypothesis, we find a positive relation on the aggregated level. Comparatively large entry cohorts in 1970 participate to an exceedingly high degree in the labour market, compared to the average. There is no evidence of intragenerational competition from a macro-level perspective.

In order to test the hypothesis on intergenerational competition between young and old workers, we were not able to refer to relative cohort size of young and old in 2004: Measuring both relative cohort sizes would cause endogeneity. Following Macunovich (2009), the size of the younger cohort is operationalised by a time lag using the mean total fertility rate in the first half of the 1980s. If fertility was high in these times, there are more young potential competitors in 2004. Empirically, there is a weak positive relation between fertility and male labour force participation (cf. Fig. 2). Therefore, we cannot support the competition hypothesis on intergenerational competition for our SHARE countries.

Educational attainment is measured by the share of older men who completed tertiary education. Figure 2 shows the positive relationship which we assumed in the theoretical part.

$\overline{2}$ For more information on the imputation methods used in SHARE see Christelis (2011). 
Fig. 2: Participation rates of men aged 50-64 in 2004 and selected indicators of socio-economic macro-level conditions in selected European countries

Male participation rate, $50-64$

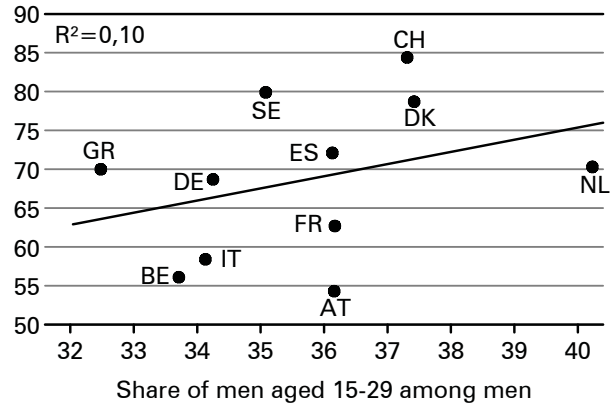

aged $15-64$ in 1970

Male participation rate, $50-64$

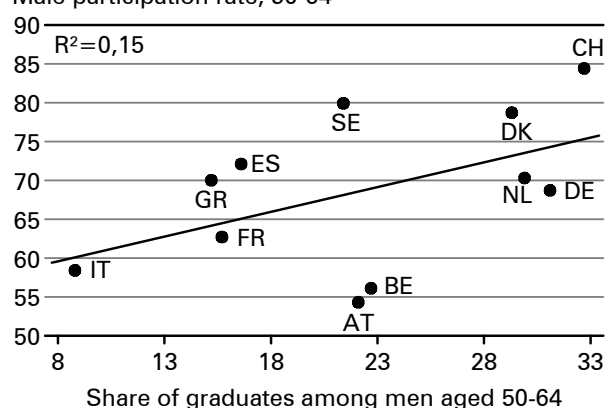

Male participation rate, $50-64$

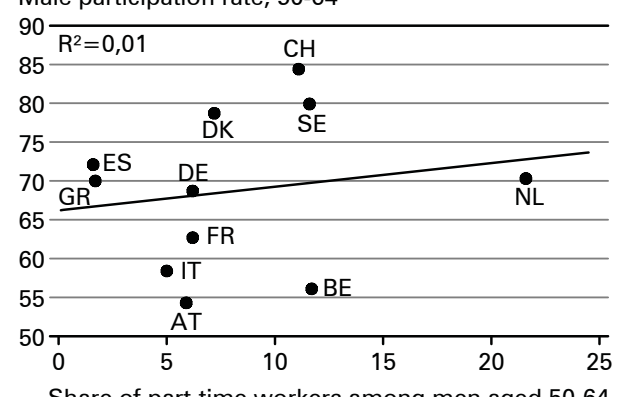

Share of part-time workers among men aged 50-64

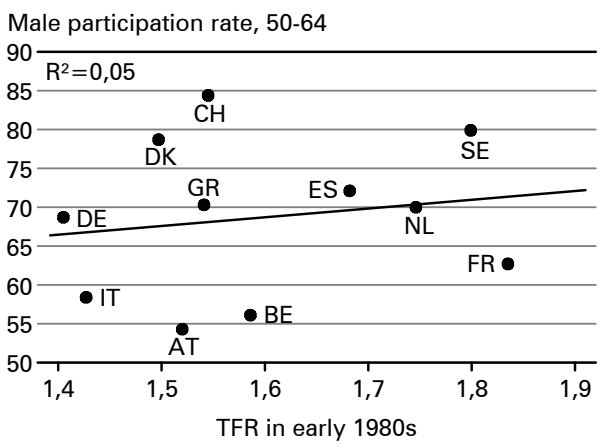

Male participation rate, $50-64$

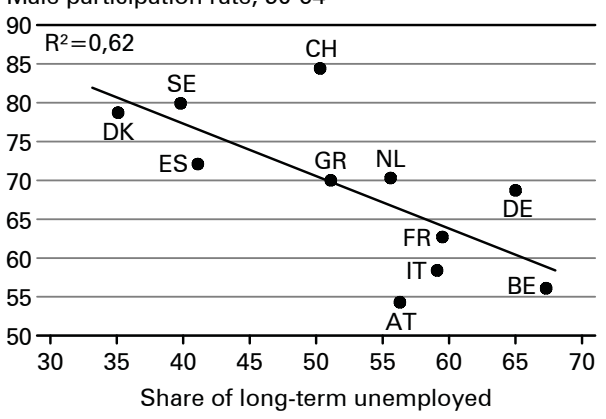

among men aged 50-64

Male participation rate, $50-64$

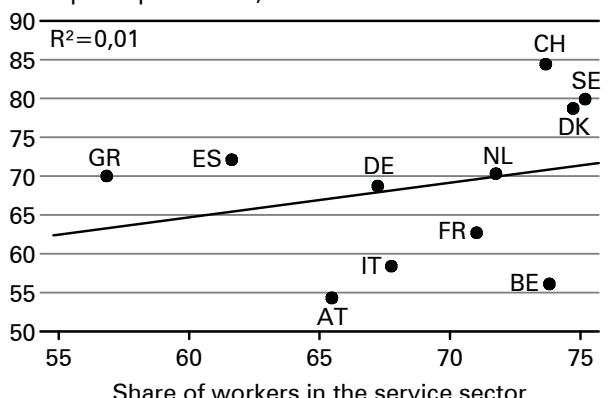

Share of workers in the service sector among men aged 50-64 
Fig. 2: Continuation
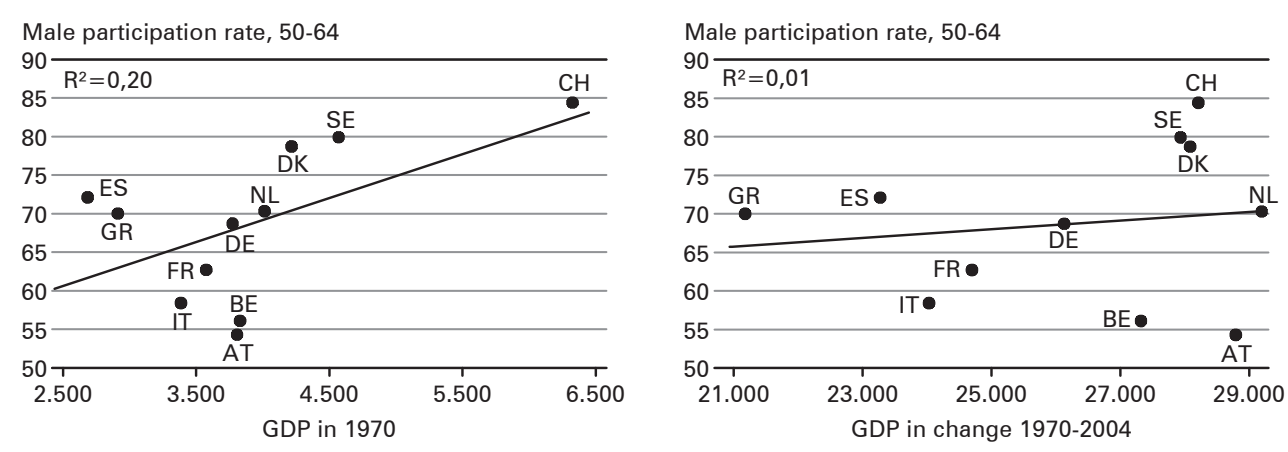

Male participation rate, $50-64$

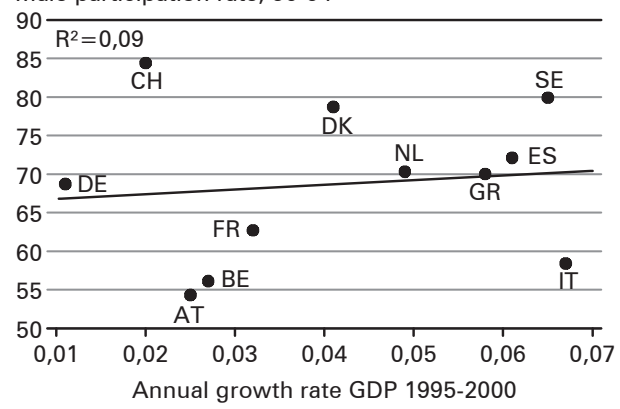

Source: $\quad$ SHARE, Version 2.5.0 and Eurostat; own calculations, $\mathrm{R}^{2}$ based on countrylevel bivariate linear regression models; data weighted according to population size.

Concerning unemployment, we tested the percentage long-term unemployed men among all aged men, who are unemployed. In line with our hypothesis, high shares of long-term unemployed correlate - at least on the macro level - with low participation rates. However, the portion of older men working part-time and the share of 50- to 64-year-old men working in service jobs are not related to labour force participation on the macro level.

In order to quantify economic concomitants, we use per capita GDP (adjusted for purchasing power parity) in US Dollars in 1970 to measure economic conditions in times of labour market entry. The change in per capita GDP between 1970 and 2004 measures long-term economic development. The mean annual growth rate of per capita GDP between 1995 and 2000 in percent controls for short-term variation at the time of planning labour market exit. GDP in 1970 shows the positive relationship assumed to exist with labour force participation. Economic growth, measured as the difference in GDP between 1970 and 2004, is however not related to labour force participation. A weak positive relationship with labour force participation is found for short-term variation in the late 1990s. 


\section{Method}

In order to estimate the effects of the determinants of labour force participation and transition to inactivity, we apply multilevel modelling. Ignoring the hierarchical structure of the data (persons nested in countries) can result in biases in parameter as well as biases in their standard errors (Guo/Zhao 2000; Rabe-Hesketh/Skrondal 2005). In order to allow for the interdependence between members of the same country, we allow for country-specific random effects. Following Engelhardt (2011), the probability of labour force participation and of transition to inactivity $p_{i j}$ may be written as:

$$
\log \left[\frac{p_{i j}}{1-p_{i j}}\right]=\beta_{0}+\beta_{1} x_{1, i j}+\cdots+\beta_{k} x_{k, i j}+u_{j}+v_{i j}
$$

Here, $i$ denotes subjects, $j$ countries, and $k$ the number of observed individual or country-level explanatory variables $x_{i j}$. The random part consists of the countryspecific error term $u_{j}$, and the error term specific to the individual $v_{i j}$. The random country effect $u_{j}$ may be interpreted as the effect of any country-specific predictors that have not been controlled for (including shared environmental factors, social contexts and norms). Similarly, the residual term for subjects within countries $v_{i j}$ may be interpreted as the effect of characteristics specific to the individual, plus measurement errors (Engelhardt 2011). Both error terms are assumed to be independently distributed, with zero means and constant within-country variance $\left(\sigma_{\downarrow} \vee \uparrow 2\right)$ and between-country variance $\left(\sigma_{u}^{2}\right)$. Adding the explanatory variables at both country and individual level will reduce the variance of the error terms. Therefore, the variance of the error terms tells us about the importance of the countrylevel variables when it comes to explaining the variance in the outcome variable. An alternative in assessing the importance of country level variables is given by the residual intra-class correlation $\rho$,

$$
\rho=\frac{\sigma_{u}^{2}}{\left(\sigma_{u}^{2}+\sigma_{v}^{2}\right)} .
$$

The residual intra-class correlation (ICC) represents the ratio of random effect variance $u$ to the total variance, and can thus be interpreted as the proportion of observed variance in the dependent variable that is accounted for by the country level. Its value decreases if the part of variance explained by the individual component increases. The percentage of variance attributable to individual-level characteristics is easily calculated by $1-\rho$.

As in the logit model, within-country variance is fixed to $\sigma_{v}^{2}=\frac{\pi^{2}}{3}$ (cf. Snijders) Bosker 1999: 213-215), changes in ICC and cross-model comparisons might be misleading as they include substantial and artificial parts (Hox 2010: 136-138). Therefore we introduce median odds ratios (MOR) as an alternative measure of cross-na- 
tional variance (Larsen et al. 2000; Larsen/Merlo 2005; Merlo et al. 2006; Merlo et al. 2009). The median odds ratio (MOR) quantifies level-two variance on the commonly used odds ratio scale, and is calculated as follows:

$$
M O R=\exp \left(\sqrt{2 \times \sigma_{u}^{2}} \times \Phi^{-1}(0.75)\right),
$$

where $\Phi^{-1}(0.75)$ is the value of the $75^{\text {th }}$ percentile of the cumulative normal distribution with zero mean and variance one. The MOR ranges from one, which means no level-two variance, to infinity. Measured level-two variance on the odds ratio scale denotes the median odds ratio between two randomly chosen persons from different clusters with the same set of covariates. This means that if a person theoretically moves to a country with a higher prevalence of being in the labour market or of resigning from it, the person's risk will (as a median) increase by the factor of MOR.

Interpreting the significance levels of the estimated coefficients and variance parameters is a pitfall in most multilevel models, as the power of those tests depends on sample size. One has to bear in mind that when testing a level-two coefficient only level-two sample size matters (Snijders 2005). As our data only include eleven countries, the power of the test that a level-two effect is statistically different from zero is limited.

An alternative measure to assess the importance of different country-level indicators is the interval odds ratio IOR (Larsen et al. 2000; Larsen/Merlo 2005; Merlo et al. 2006; Merlo et al. 2009). The IOR covers an arbitrarily-selected interval centred on the median of the odds ratios' distribution for all possible pairs with identical covariates except for residence. The 80 percent interval is commonly used. Bounds are calculated as: ${ }^{3}$

$$
\begin{aligned}
& I O R_{\text {lower }}=\exp \left(\beta \times\left(x_{1}-x_{2}\right)+\sqrt{2 \times \sigma_{u}^{2}} \times \Phi^{-1}(0.10)\right) \\
& I O R_{\text {upper }}=\exp \left(\beta \times\left(x_{1}-x_{2}\right)+\sqrt{2 \times \sigma_{u}^{2}} \times \Phi^{-1}(0.90)\right),
\end{aligned}
$$

with $\beta$ being the regression coefficient of the particular country-level indicator and $x_{1}$ respectively $x_{2}$ being the contrasting values of this indicator. The lower bound is set to the $10^{\text {th }}$ percentile of the cumulative normal distribution in case of IOR80. Therefore the upper bound refers to the $90^{\text {th }}$ percentile. Although IOR is not a confidence interval, it is important to see whether the interval contains the value one. The effect of a country-level indicator is large in comparison to the residual

3 Theoretical derivations of the formulas for calculating MOR and IOR are described in the appendix of Larsen and Merlo (2005). 
level-two variance if it does not contain the value one. IOR otherwise suggests a weak impact of the indicator mentioned. Such a result is mostly in line with a comparatively wide range covered by the IOR, which denotes large residual variance on the country level.

\section{$4 \quad$ Results}

The starting point of the multilevel analysis is a model including only individuallevel covariates. This benchmark model allows us to assess the explanatory power of country-level covariates as we add them progressively. In order to compare the impact of different variables, we use standardised beta coefficients. We present the estimated variances of the country-specific error term, the ICC and the MOR for each model specification. Estimated variances give us an idea of the extent to which inter-country differences are explained by macro-level variables. Additionally, we calculate the IOR in order to assess the importance of individual indicators. The ICC coefficient shows the remaining variance at the country level as against the individual level. MOR tells us about the residual effect of moving theoretically to a country with higher values on the respective indicator. The ICC and MOR fall in most cases if one adds the macro variables that explain country differences.

\section{Labour force participation}

Model M1-0 in Table 2 shows the results from the multilevel logistic regression analysis of men's labour force participation without any covariates on the national level. The intra-class correlation coefficient ICC measures the share of variance in the dependent variable attributable to unobserved country-level characteristics. The ICC amounts to 0.079 if one controls for individual-level covariates. Thus, 7.9 percent of the variance in the propensity of labour force participation in Europe can be attributed to unobserved country-specific factors, if we control for cross-national sample composition with respect to our individual-level covariates. At first sight, the small share of variance, which is due to the country level, seems insufficient to justify multilevel methods. If one however allows for the fact that the countries under investigation are quite similar when it comes to their welfare state arrangements, we argue that this remaining share needs to be explained. The estimated residual between-country variance is about 0.28 . The MOR expresses this residual variance on the odds ratio scale, and amounts to 1.66. If a person coming from a country with a low propensity for labour market participation moves to a country with a higher propensity, his probability of labour participation will increase 1.66 
952 - Henriette Engelhardt, Christopher Schmidt

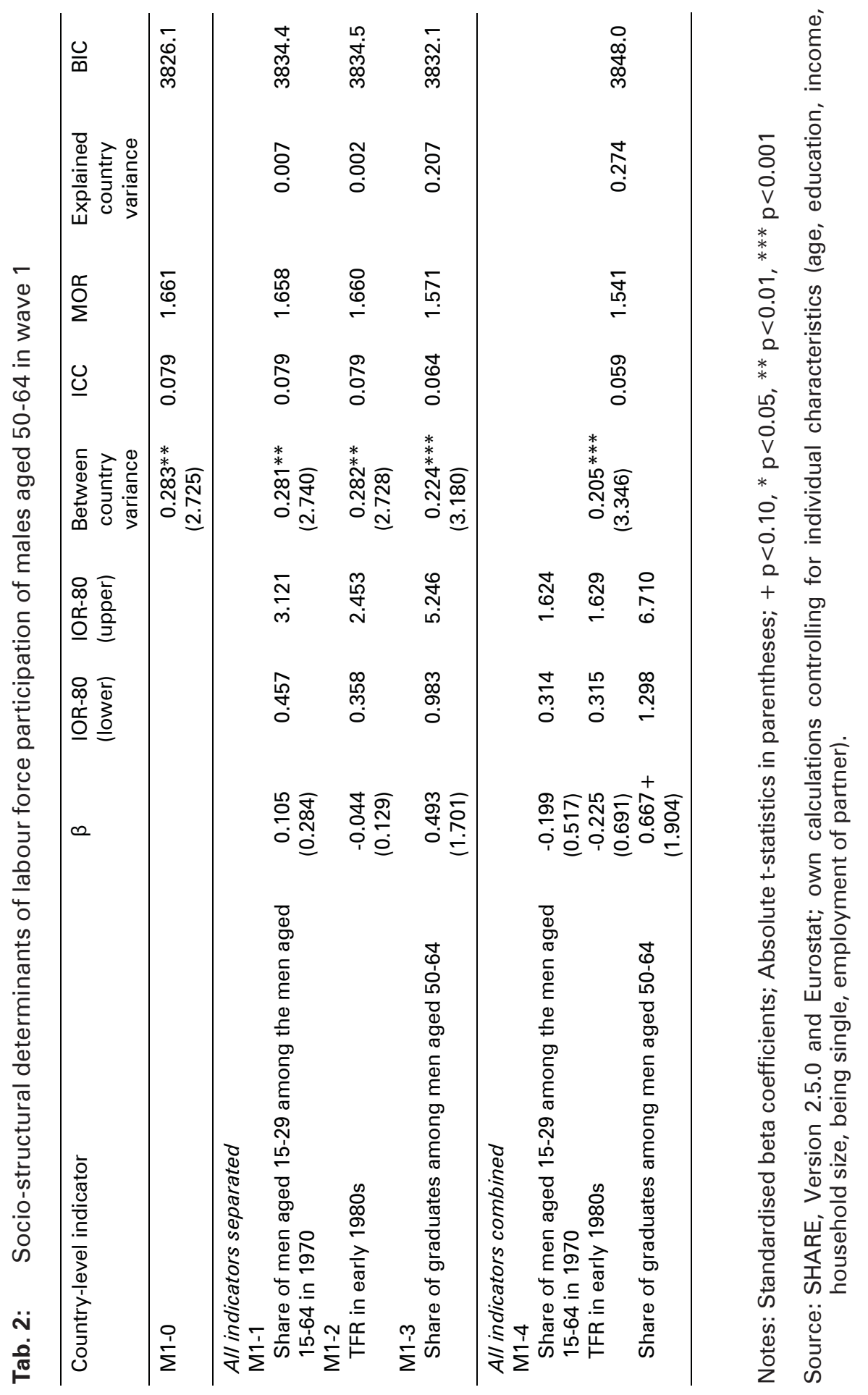


times in the median. As we add certain country level variables (Tables 2 to 4), we see a reduction in both ICC and MOR. ${ }^{4}$

On the national level, the first indicator considering social structure is introduced in model M1-1. The effect of the share of males aged 15 to 29 in 1970, however, is not significantly different from zero. The same applies to the mean fertility rate in the early 1980s, which is presented in model M1-2. IOR-80 contains one for both indicators. ICCs and MORs remain virtually unchanged, and residual variance is not reduced by adding these indicators to the model.

In contrast, the effect of educational attainment indicates that the chance to participate in the labour market increases significantly with the share of male graduates in the population (model M1-3). Although t-statistic is only 1.7, IOR-80 contains the value one just slightly and confirms the importance of this indicator. ICC, MOR and the explained country-level variance reinforce this result. More than 20 percent of level-two variance can be attributed to the educational level of older workers. The MOR drops from 1.68 to 1.57. If a person coming from a country with a low propensity for labour market participation moves to a country with a higher propensity, but with the same educational attainment among the elderly, his own probability to be in the labour market will increase only 1.57 times in the median.

Model M1-4 brings the indicators of social structure together. But results do not change remarkably, with the exception that the effect of educational attainment among the elderly is significant at the 10 percent level. Accordingly, we have to conclude that labour market participation only varies with the share of older workers with at least tertiary education across the national sample. There is statistical evidence neither for Easterlin nor for the substitution hypothesis concerning labour market participation, although both indicators point to the assumed directions. The lack of statistical evidence might be due to the low number of cases at national level. Altogether, indicators of social structure explain 27.4 percent of cross-national variance and they reduce the MOR to 1.54 .

Table 3 contains models in which we control for the indicators of national labour market structures. Again, model M1-0 serves as a benchmark with reference to cross-national variance and the impact of level-2 indicators.

Model M1-5 reveals that labour force participation decreases significantly with an increasing share of older males being long-term unemployed. The IOR is narrow and smaller than one. Residual between-country variance is clearly reduced to 0.185 , which results in a residual ICC of 5.3 percent. Therefore, the incidence of long-term unemployment among the unemployed elderly explains more than

4 Concerning the covariates at the individual level, the estimated standardised coefficients show the expected effects and remain consistent with regard to content for different model specifications, also in cases where the country-level variables are added. As predicted, the likelihood of being part of the active labour force decreases significantly with age, whilst it increases with higher education and is reduced where health is sub-optimal. Moreover, the probability of labour force participation is increased for high income households and in larger households. With an employed partner, labour force participation is significantly increased, this is also applying when no partner is present. See the appendix for the coefficients on the individual level. 
954 - Henriette Engelhardt, Christopher Schmidt

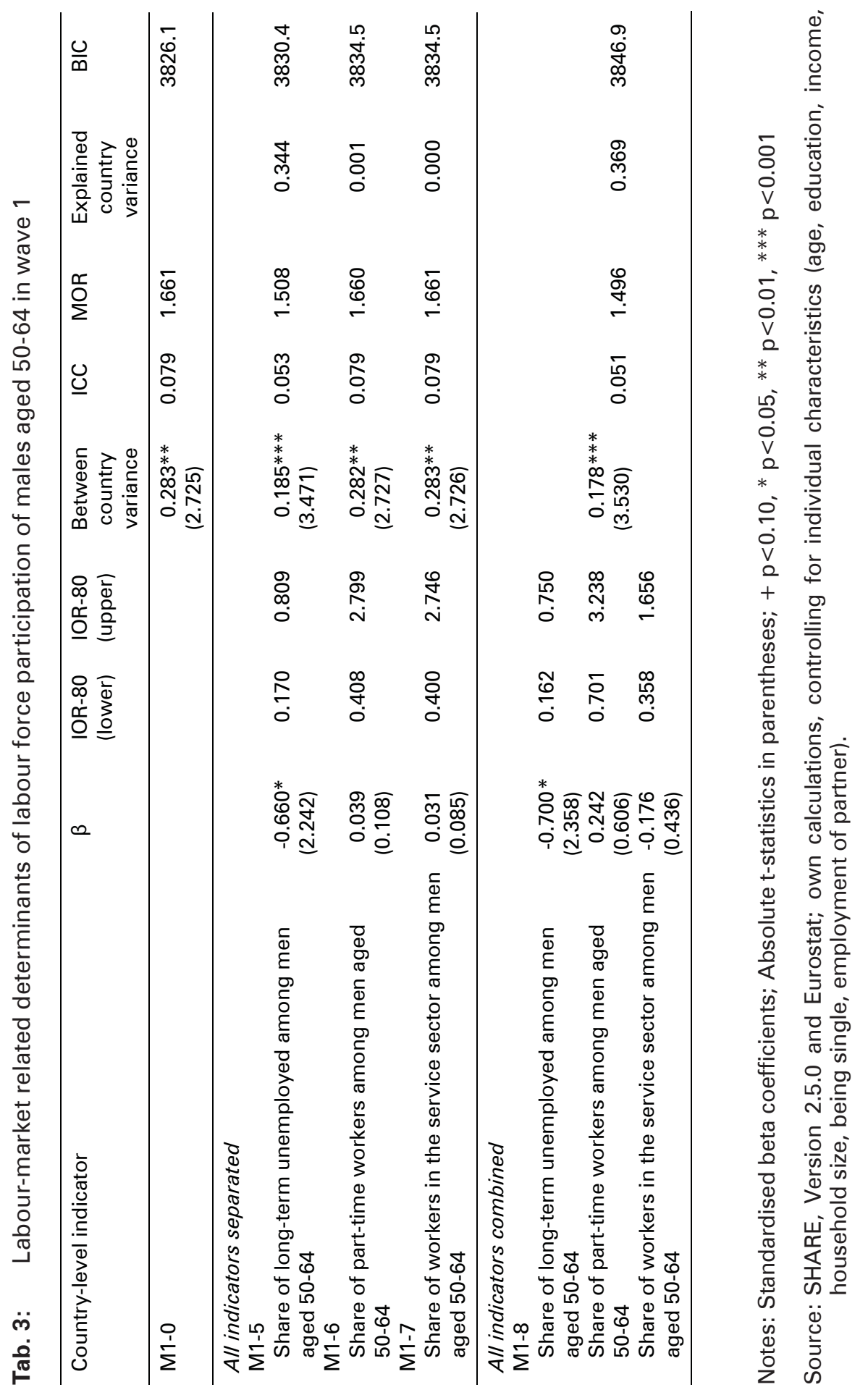


34 percent of cross-national variance. Residual MOR is reduced to 1.508. Long-term unemployment obviously explains cross-national variance to a greater extent than all indicators of social structure taken together.

The share of male part-time workers aged 50 years and older and the share of older males employed in the service sector, however, have no effect significantly different from zero (M1-6 and M1-7). Therefore, ICC remains at 7.9 percent and the IORs cover comparatively broad ranges both including 1.

These results do not change even if we estimate the effects controlling for all labour market-related determinants (M1-8). ICC, MOR and the proportion of explained country variance approximately equal those of the incidence of long-term unemployment. Hence, we do not find any evidence of our hypotheses concerning part-time work and service jobs facilitating older men's labour market participation. Long-term unemployment, however, seems to be a predominantly involuntary status, and exits into retirement are realised as soon as possible. Therefore, living in a country with a high level of long-term unemployment among older unemployed men decreases the chance to participate in the labour force in 2004.

Table 4 presents the results with regard to economic determinants of labour force participation.

In comparison to the benchmark model M1-0, model M1-9 includes economic conditions at times of labour market entry of today's older workers. The effect of economic entry conditions is positive, but not significant. Nevertheless, the IOR hardly includes the value one which indicates at least some importance of per capita GDP at labour market entry. Additionally, ICC is reduced to 7 percent, which results in an explained proportion of cross-national variance of 11.9 percent.

In contrast, long-term and short-term variations in economic growth do not show the expected association to the propensity of labour force participation (M1-10 and M1-11). Their estimated effects are not statistically significant although they point in the anticipated directions. However, controlling for economic entry conditions alters this result to some extent. Entry conditions themselves become significant (M1-12). Though long-term growth measured as the change in per capita GDP from 1970 to 2004 is still not significant, the IOR includes such a change to a comparatively slight degree. This indicates at least some importance attaching to economic long-term economic growth for cross-national differences in propensity to participate in the labour force. Short-term variation in economic growth measured as the mean annual growth rate of GDP between 1995 and 2000, however, is not related to international variance in labour market participation.

Taking all economic determinants into account explains 29.0 percent of betweencountry variance. Entering the labour market under comparatively favourable conditions increases the chance to participate in the labour force even at higher ages, which is in line with our hypothesis. On the other hand, stronger long-term economic growth decreases the likelihood. Hence we have to assume that long-term economic growth increases wealth and enables people to leave the labour force. If anything, short-term growth rather keeps people in the labour market. Nevertheless, economic concomitants explain the smallest share of cross-national variance concerning labour market participation. 
956 - Henriette Engelhardt, Christopher Schmidt

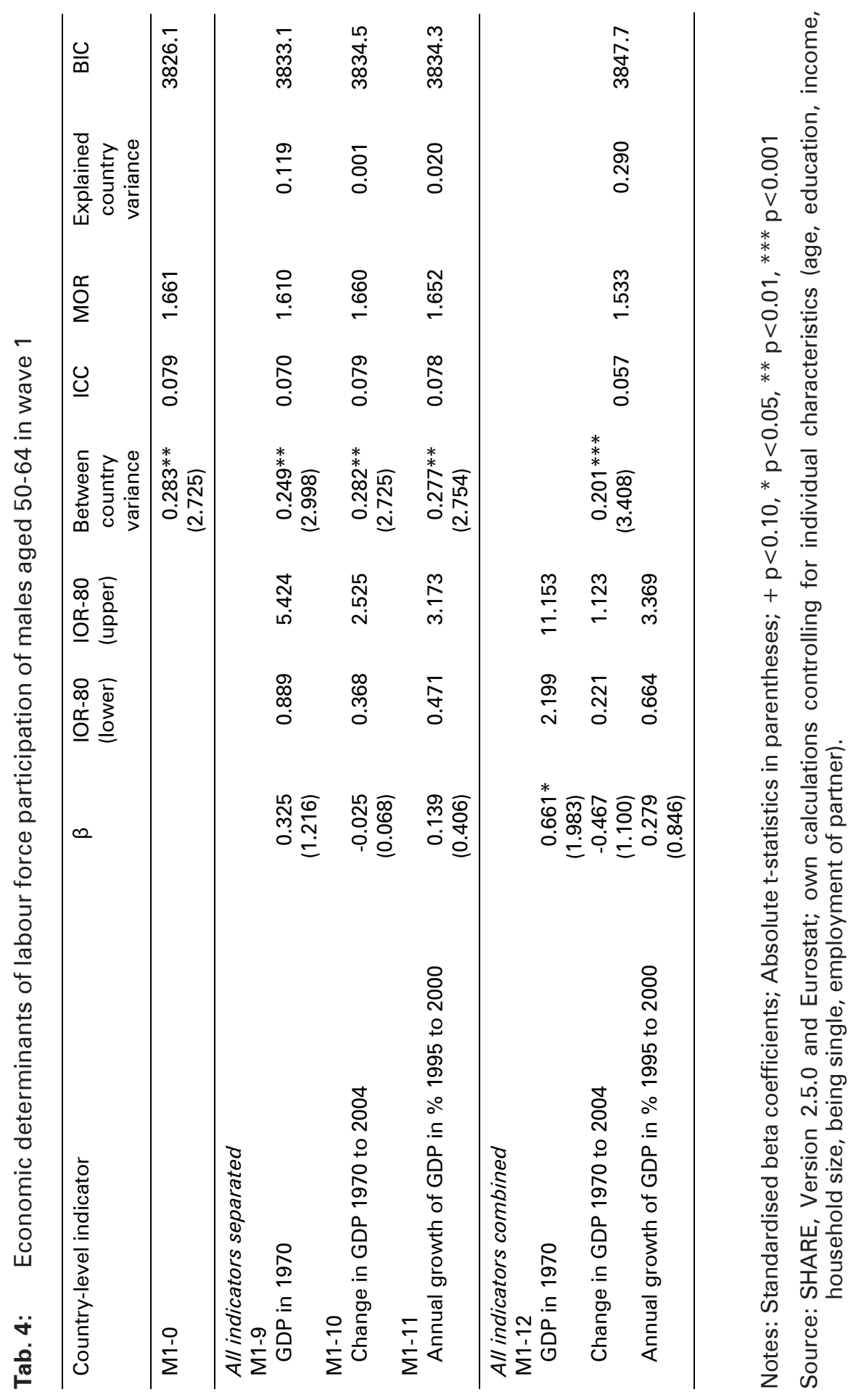


It is not surprising that the effects of the economy are interdependent, as entry conditions provide the initial state of economic growth. Thus, explained cross-national variance should increase anyway. We tested each combination of these indicators by introducing interaction terms in separated models to rule out disturbed main effects. Interaction terms did not improve our models, and are omitted from Table 4.

\section{Transition to inactivity}

Table 5 to 7 present results from the multilevel logistic regression analysis of men's transition into inactivity. As most voluntary exits from the labour market take place well before formal retirement ages, we restrict our analyses to men between the ages of 50 and 61 in the first wave of the data.

As model M2-0 shows, about 9.2 percent of the variance in the transition to inactivity in Europe can be explained by country-specific factors. Thus, about 91 percent of the observed variance in the dependent variable can be attributed to individual-level characteristics. MOR nevertheless indicates the country level as a decisive factor of early exit from the labour market. If a person moves to a country with a theoretically higher propensity of early exit, his own risk increases by more than 1.73 times in the median. We can therefore conclude that the country level is more important for the early transition to inactivity than it is for explaining participation in the labour market until the age of $64 .^{5}$

Looking at model M2-1 in Table 5, we see that controlling for the relative cohort size of today's older workers reduces level-2 variance from 0.331 to 0.270 . ICC and MOR decrease to 7.6 percent respectively 1.64 which is in accordance with a variance reduction of 18.5 percent at the country level. Notwithstanding, the estimated effect in model M2-1 is not significantly different than zero. Additionally, the IOR includes the value one. Nevertheless, this effect is considerably large compared to the effects of the TFR in the early 1980s and of the educational attainment of older workers (M2-2 and M2-3). Those indicators do not show any remarkable reduction in variance with reference to early labour market exit.

The impact of relative cohort size at labour market entry is furthermore highlighted in model M2-4. The positive effect becomes statistically significant if we control for social structure collectively. This result confirms the Easterlin hypothesis. The individual risk of early exit increases in a country in which today's older workers

5 The individual-level variables largely show the expected effects. In the countries under study, the likelihood of leaving the active labour force predictably increases significantly with age and where health is sub-optimal, and is significantly reduced in case of tertiary education compared to lower-than-secondary education. As to the household, the probability of labour market exit is significantly decreased for respondents belonging to high income households. With an employed partner or when no partner is present, the probability of respondents' transition to inactivity is significantly reduced. Concerning job characteristics, employment exit is significantly less likely for self-employed men and for men who are satisfied with their jobs. No significant effects are found to result from firm size, the public sector and the tertiary sector, albeit the signs of the sector effects are in line with our expectations. See the appendix for the coefficients on the individual level. 
958 - Henriette Engelhardt, Christopher Schmidt

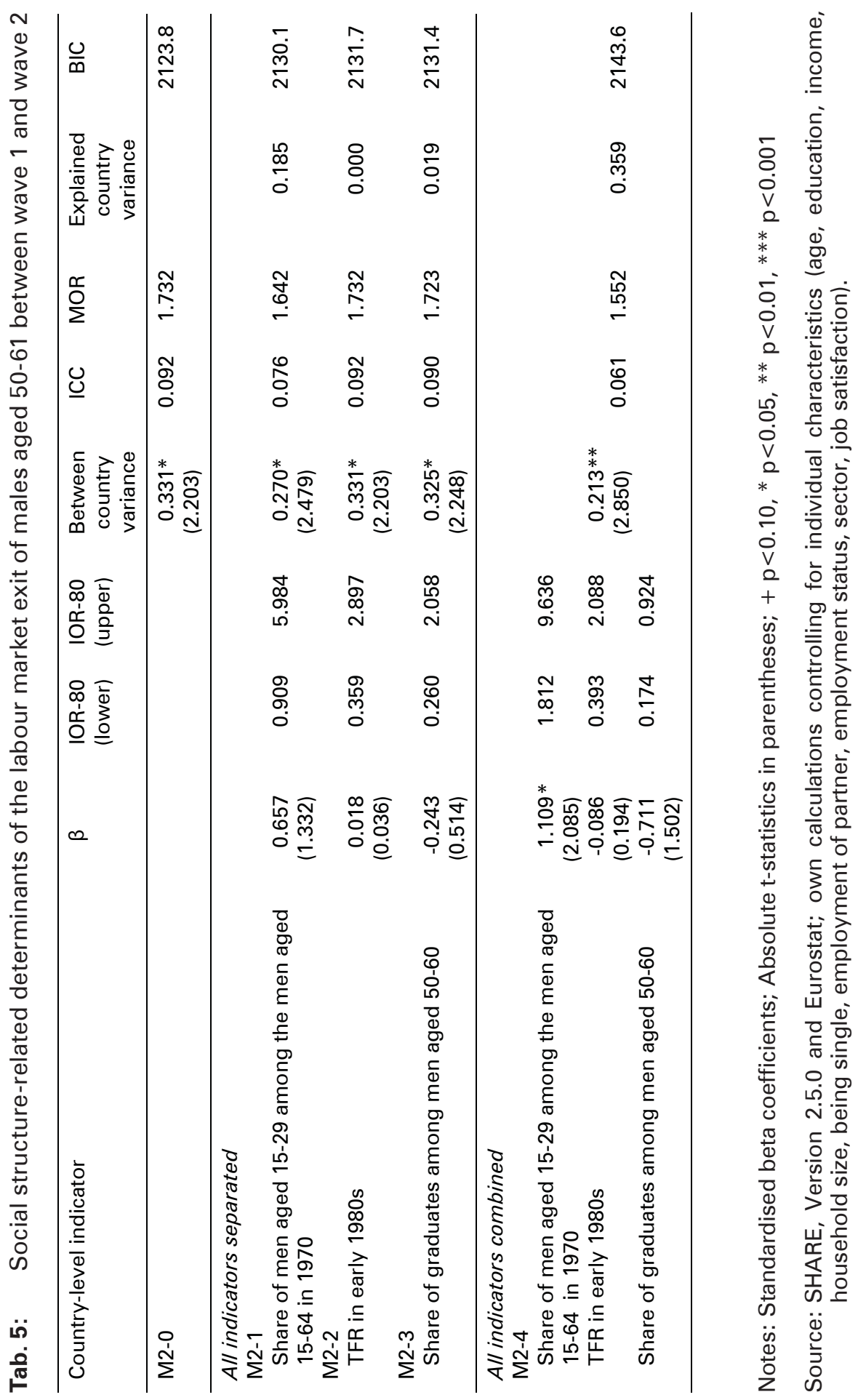


are part of a large entry cohort compared to other countries. Although the other indicators of social structure remain insignificant with a large IOR containing the value one, explained variance increases to 35.9 percent. Residual MOR is reduced to 1.55 , which almost equals the value of MOR concerning labour force participation. As MOR is comparable across different models, this indicates the exceeded impact of social structure for early exit, on the one hand, and the stable fraction of unexplained variance, on the other.

Table 6 contains the results for labour market-related determinants. Introducing these indicators does not change the effects of individual-level characteristics.

Labour market structure, in particular the incidence of long-term unemployment, explains almost 37 percent of variance concerning labour force participation (Table 3, model M1-8). Long-term unemployment among the elderly reduces residual MOR to 1.50 by itself (Table 3, model M1-5). In contrast, labour market structures explain just about 20 percent with regard to early labour market exit (M2-8). The residual MOR in respect of labour market exits remains at about 1.66 after controlling for long-term unemployment (M2-5). Although this equates to a proportional reduction of variance, reaching more than 15 percent, we do not find any evidence of a meaningful relationship with early exit on an individual level. The effect is statistically insignificant, and the broad IOR obviously contains the value one. As for the share of older part-time workers and males in service jobs (M2-6 and M2-7), there is no statistical evidence of a systematic relationship with the individual risk of early exit. This result even remains constant in model M2-8, where we control for labour market structures simultaneously.

Table 7 shows the estimation results for economic determinants of early labour market exit.

In model M2-9, we see that GDP in times of labour market entry is negatively related to early labour market exit, this being in line with our hypothesis. Although the effect is not significantly different for zero, IOR slightly contains the value one. This indicates some importance at least. We nonetheless have to assume that the economic situation in times of labour market entry marginally influences individual exit probability, as ICC and MOR are reduced only fractionally. The same holds true for long-term economic growth measured as the change in GDP between 1970 and 2004 and short-term growth measured as the mean annual growth rate of GDP between 1995 and 2000 (M2-10 and M2-11). These indicators actually explain 8 percent and 2.2 percent, respectively, of cross-national variance and their IOR clearly includes the value one.

Looking at model M2-12, which controls for all indicators simultaneously, we find different results. The estimated directions of economic concomitants remain stable, but the starting conditions and long-term growth are significantly different than zero, with IORs clearly excluding the value one. ICC decreases to 4.1 percent equivalent to a reduction of variance of 57.8 percent. Residual MOR declines to 1.43 , which is the smallest value measured across all models. As we have already stated, these indicators are interdependent, although they do not interact. These results remain stable if we skip the annual growth rate between 1995 and 2000 in M2-12 (not shown here). 
960 - Henriette Engelhardt, Christopher Schmidt

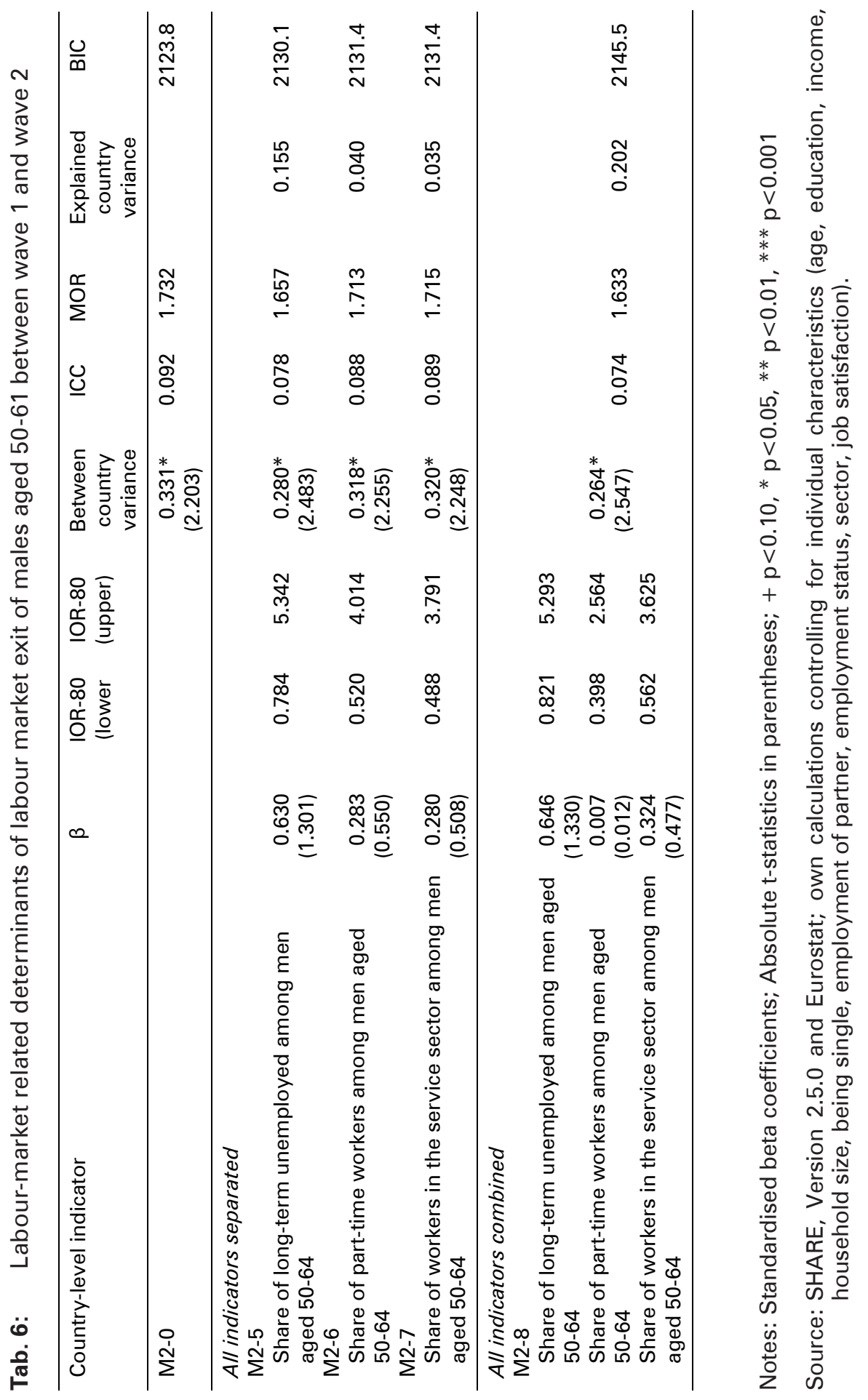




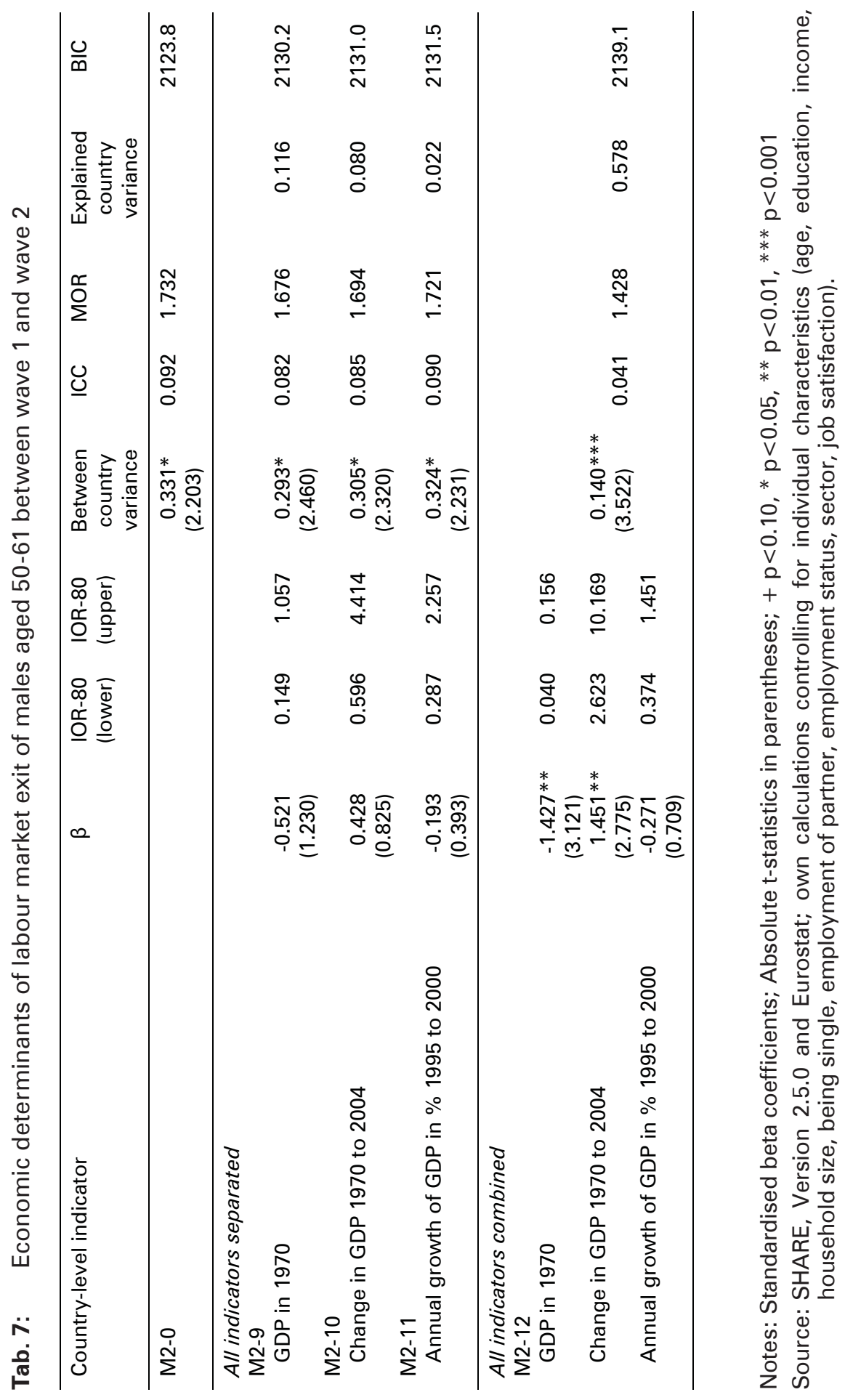


A comparatively good economic situation when entering the labour market facilitates career opportunities. As a consequence, the probability of early labour market exit is lower in countries where GDP was comparatively high when today's older workers entered the labour market. This long-term effect is offset by the change in GDP between 1970 and 2004. The more GDP increased over time, the higher are today's country-specific early exit probabilities. These findings suggest that economically favourable circumstances at labour-market entry diminish early exit probability by stabilising careers, whereas economic upswing enhances wealth and therefore increases the likelihood of early exit. Again, the negative effect of short-term growth between 1995 and 2000, although not significant, suggests that favourable economic conditions at the threshold to late career retain the elderly in the labour market.

\section{Conclusion}

This article investigates the labour force participation and transition to inactivity of older men in eleven European countries using the first two waves of SHARE merged with country-level variables from Eurostat. The macro data focus on the age structures as well as on indicators of the labour market and the economy in the countries under investigation. We use multilevel methods in order to estimate the proportion of variance in labour participation and labour exit linked to country-specific characteristics. Using the same analytical framework as Engelhardt (2011) allows us to quantify the relative impact of different structural indicators.

To sum up, cross-national variance is comparatively small concerning labour market participation and transition to inactivity among the countries of SHARE (7.9 percent and 9.2 percent). If one however takes a closer look at the countries participating in the first two waves, it must be admitted that the absence of liberal and post-socialist countries entails relative homogeneity in our sample of countries. Our analysis nonetheless demonstrates that the labour force participation and transition to inactivity of older men varies with country-specific characteristics, most notably other than institutional arrangements. Cross-national differences in individual labour force participation correlate with the prevalence of country-specific long-term unemployment and the educational level of the elderly. A large share of long-term unemployed decreases the probability of individual labour force participation. Obviously long-term unemployment is mainly involuntary and an exit from the labour market is realised as soon as possible. Accordingly, long-term unemployment is positively related to early exit, although this effect is not significant in our analysis. In contrast, a large share of highly-educated older men increases the individual probability to participate in the labour market. This result is clearly in line with our hypothesis. It confirms the argument that a large share of tertiary-educated men among the elderly reduces competition for low-skilled jobs where young and old workers are actual substitutes. Thus, it is hardly surprising that our hypotheses of intra- and intergenerational competition are only supported if one controls for the educational attainment of older men. Although effects are not significantly different 
than zero, the relative cohort size and the size of subsequent cohorts decrease individual participation probability as competition increases, if we control for the share of tertiary-educated aged workers. Alternatively, varying country-specific educational levels conceal these differences. In contrast to our hypotheses, economic concomitants play an only minor role when it comes to explaining cross-national differences in labour force participation. This might be explained by generous welfare state arrangements in which unemployment benefits keep jobless people in the labour market.

In contrast, economic concomitants play a major role when it comes to explaining cross-national differences in transition to inactivity. In line with our hypothesis, GDP at labour-market entry is negatively related to early exit. Workers in countries with a high GDP at labour market entry show a comparably low probability to exit early. The development of per capita GDP between 1970 and 2004, however, stimulates a withdrawal from working life. Workers show a higher probability to exit early in countries in which GDP had grown considerably. Therefore, we might argue that economic expansion over these 35 years induced wealth in prospering countries. This might encourage workers to realise a preference for leisure or induce governments to expand old-age benefits. If at all, short-term variation in economic growth seems to keep the elderly in the labour-market. Besides economic concomitants, early exit probabilities vary considerably with social structure. Especially intragenerational competition crystallises as a meaningful predictor of cross-national variance, as the individual probability of an early exit increases with the relative size of one's own entry cohort.

Summing up, our analysis demonstrates that socio-economic structures explain cross-national differences in labour force participation and transition to inactivity to a fairly large extent. A final appreciation of the effects requires additional control of institutional factors. Long-term unemployment, for example, is linked to employment protection legislation. So the question whether the estimated effect is due to the institutional regulation or to its social consequence cannot be answered so far. This result should be kept in mind even if institutional effects are under investigation. There is a well-established theoretical primacy of institutional explanations of cross-national differences in late careers. As our results show, there are other factors influencing cross-national differences. As far as we are aware, no study has yet attempted to disentangle institutional and social factors with regard to labour market participation and labour market exit in a multi-variate and multi-level framework.

\section{References}

Acemoglu, Daron 2002: Technical Change, Inequality, and Labor Market. In: Journal of Economic Literature XL: 7-72 [doi: 10.1257/0022051026976].

Auer, Peter; Fortuny, Mariànge/s 2000: Aging of the Labour Force in OECD Countries: Economic and Social Consequences. ILO Employment Paper 2000/2. Geneva: International Labour Office. 
Bellmann, Lutz; Janik, Florian 2007: Firms and Early Retirement: Offers That One Does Not Refuse. IZA Discussion Paper No. 2931. Bonn [doi: 10.1007/s12651-009-0023-9].

Bils, Mark J. 1985: Real Wages over the Business Cycle: Evidence from Panel Data. In: Journal of Political Economy 93,4: 666-689 [doi: 10.1086/261325].

Blöndal, Sveinbjörn; Scarpetta, Stefano 1998: The Retirement Decision in OECD Countries. OECD Working Paper No. 202, OECD Economics Department.

Bloom, David E.; Freeman, Richard B.; Korenman, Sanders D. 1987: The Labour-Market Consequences of Generational Crowding. In: European Journal of Population 3: 131176.

Blossfeld, Hans-Peter 1987: Labor-Market Entry and the Sexual Segregation of Careers in the Federal Republic of Germany. In: The American Journal of Sociology 93,1: 89118.

Blossfeld, Hans-Peter 1989: Kohortendifferenzierung und Karriereprozess. Eine Längsschnittstudie über die Veränderung der Bildungs- und Berufschancen im Lebenslauf. Frankfurt/Main: Campus.

Blossfeld, Hans-Peter; Buchholz, Sandra; Hofäcker, Dirk (Eds.) 2006: Globalization, Uncertainty and Late Careers in Society. London/New York: Routledge [doi: 10.2383/25962].

Börsch-Supan, Axel; Jürges, Hendrik (Eds.) 2005: The Survey of Health, Ageing and Retirement in Europe: Methodology. Mannheim: Mannheim Research Institute for the Economics of Ageing (MEA) [doi: 10.1093/ije/dyt088].

Börsch-Supan, Axel; Brugiavini, Agar; Croda, Enrica 2009: The role of institutions and health in European patterns of work and retirement. In: Journal of European Social Policy 19: 341-358 [doi: 10.1177/1350506809341515].

Bosch, Gerhard; Schief, Sebastian 2007: Older Employees in Europe between 'Work Line' and Early Retirement. In: Transfer: European Review of Labour and Research 13,4: 575-593 [doi: 10.1177/102425890701300405].

Bosworth, Barry P.; Burtless, Gary 2010: Recessions, Wealth Destruction, and the Timing of Retirement. Center for Retirement Research Working Paper 2010-22. Center for Retirement Research at Boston College [doi: 10.2139/ssrn.1719604].

Bound, John; Turner, Sarah 2007: Cohort Crowding: How Resources Affect Collegiate Attainment. In: Journal of Public Economics 91: 877-899 [doi: 10.1016/j. jpubeco.2006.07.006]

Bover, Olympia; Arellano, Manuel; Bentolila, Samuel 2002: Unemployment Duration, Benefit Duration and the Business Cycle. In: The Economic Journal 112: 223-265 [doi: 10.1111/1468-0297.00034].

Brunner, Beatrice; Kuhn, Andreas 2010: The Impact of Labor Market Entry Conditions on Initial Job Assignment, Human Capital Accumulation, and Wages. IZA Discussion Paper No. 5360. Bonn [doi: 10.2139/ssrn.1722160].

Brussig, Martin; Wübbeke, Christina 2009: Policy-Making in Ageing Labour Markets: The Case of Hidden Early Retirement in Germany. In: Kuhn, Michael; Ochsen, Carsten (Eds.): Labour Markets and Demographic Change. Wiesbaden: VS Verlag: 252-280 [doi: 10.1007/978-3-531-91478-7_13].

Buchholz, Sandra; Hofäcker, Dirk; Blossfeld, Hans-Peter 2006: Globalization, Accelerating Social Change and Late Careers: A Theoretical Framework. In: Blossfeld, HansPeter; Buchholz, Sandra; Hofäcker, Dirk (Eds.): Globalization, Uncertainty and Late Careers in Society. London/New York: Routledge: 1-23 [doi: 10.2383/25962] 
Card, David; Lemieux, Thomas 2001: Can Falling Supply Explain the Rising Return to College for Younger Men? A Cohort-Based Analysis. In: The Quarterly Journal of Economics 116: 705-746 [doi: 10.1162/00335530151144140].

Castel/s, Manuel 2000: The Rise of the Network Society: The Information Age. Economy, Society and Culture. Oxford: Blackwell Publishers.

Chan, Sewin; Stevens, Ann Huff 2001: Job Loss and Employment Patterns of Older Workers. In: Journal of Labor Economics 19, 2: 484-521 [doi: 10.1086/319568].

Christelis, Dimitris 2011: Imputation of Missing Data in Waves 1 and 2 of SHARE. SHARE - Survey of Health, Ageing and Retirement in Europe. Working Paper Series 01-2011. Mannheim [doi: 10.2139/ssrn.1788248].

Currie, Janet; Madrian, Brigitte C. 1999: Health, health insurance and the labor market. In: Ashenfelter, Orley; Card, David (Eds.): Handbook of Labor Economics. Amsterdam: North Holland: 3309-3416.

Darby, Julia; Hart, Robert A.; Vecchi, Michela 2001: Labour Force Participation and the Business Cycle: A Comparative Analysis of France, Japan, Sweden and the United States. In: Japan and the World Economy 13: 113-133 [doi: 10.1016/S09221425(00)00049-9].

Debrand, Thierry; Sirven, Nicholas 2009: What are the Motivations of Pathways to Retirement in Europe: Individual, Familial, Professional Situation or Social Protection Systems? IREDS Working Paper DT $\mathrm{n}^{\circ} 28$. Paris.

Delsen, Lei 1996: Gradual Retirement: Lessons from the Nordic Countries and the Netherlands. In: European Journal of Industrial Relations 2: 55-67.

Dereveux, Paul J. 2000: Task Assignment over the Business Cycle. In: Journal of Labor Economics 18,1: 291-309 [doi: 10.1086/209952].

DiPrete, Thomas A. et al. 1997: Collectivist versus Individualist Mobility Regimes? Structural Change and Job Mobility in Four Countries. In: The American Journal of Sociology 103,2: 318-358.

Dorn, David; Souza-Poza, Alfonso 2010: Voluntary and involuntary early retirement. An international analysis. In: Applied Economics 42,4: 427-438 [doi: 10.1080/00036840701663277].

Drobnič, Sonja 2002: Retirement Timing in a Household Context. In: International Journal of Sociology 32,2: 75-102.

Easterlin, Richard A. 1980: Birth and Fortune: The Impact of Numbers on Personal Welfare. New York: Basic Books.

Eichhorst, Werner 2006: Beschäftigung Älterer in Deutschland: Der unvollständige Paradigmenwechsel. IZA Discussion Paper No. 1985. Bonn.

Eichhorst, Werner 2011: The Transition from Work to Retirement. IZA Discussion Paper No. 5490. Bonn [doi: 10.1093/geronb/gbs049].

Elsby, Michael; Hobijn, Bart; Şahin, Aysegül 2010: The Labor Market in the Great Recession. In: Brookings Papers on Economic Activity 2010,1: 1-48 [doi: 10.1353/ eca.2010.0001].

Engelhardt, Henriette 2011: Late Careers in Europe: Effects of Individual and Institutional Factors. In: European Sociological Review, published online April 14, 2011 [doi: 10.1093/esr/jcr024]. 
Engelhardt, Henriette; Schmidt, Christopher 2011: Late Careers and Socio-Economic Structures in Europe. Chair of Population Studies at the University of Bamberg. Discussion Paper Series No. DP 10/2011 [URL: http://www.uni-bamberg.de/demografie, 07.11.2012].

Eurostat 2010: Statistics by theme [URL: http://epp.eurostat.ec.europa.eu/portal/page/ portal/statistics/themes, 28.05.2011].

Garloff, Alfred; Pohl, Carsten; Schanne, Norbert 2010: Do Smaller Labor Market Entry Cohorts Really Reduce German Unemployment? EALE Conference Paper. June 2010, London.

Guo, Guang; Zhao, Hongxin 2000: Multilevel Modelling for Binary Data. In: Annual Review of Sociology 26: 441-462 [doi: 10.1146/annurev.soc.26.1.441].

Hairault, Jean-Olivier; Langot, François; Sopraseuth, Thepthida 2010: Distance to Retirement and Older Workers' Employment: The Case for Delaying the Retirement Age. In: Journal of European Economic Association 8,5: 1034-1076 [doi: 10.1111/j.15424774.2010.tb00547.x].

Hamermesh, Danie/ S. 1993: Labor Demand. Princeton, New Jersey: Princeton University Press.

Hutchens, Robert 1986: Delayed Payment Contracts and a Firm's Propensity to Hire Older Workers. In: Journal of Labor Economics 4,4: 439-457.

Hofäcker, Dirk 2010: Older Workers in a Globalizing World. Cheltenham, UK: Edward Elgar [doi: 10.3384/ijal.1652-8670.1271A].

Hox, Joop J. 2010: Multilevel Analysis: Techniques and Applications, 2nd Edition. New York: Routledge.

Kahn, Lisa B. 2010: The Long-Term Labor Market Consequences of Graduating from College in a Bad Economy. In: Labour Economics 17,2: 303-316 [doi: 10.1016/j. labeco.2009.09.002].

Kalwij, Adriaan; Kapteyn, Arie; de Vos, Klaas 2009: Early Retirement and Employment of the Young. Netspar - Network for Studies on Pensions, Ageing and Retirement. Discussion Paper 03/2009 - 012. Tilburg [doi: 10.2139/ssrn.1508429].

Keister, Lisa A.; Deeb-Sossa Natalia 2001: Are Baby Boomers Richer Than Their Parents? Intergenerational Patterns of Wealth Ownership in the United States. In: Journal of Marriage and Family 63: 569-579 [doi: 10.1111/j.1741-3737.2001.00569.x].

Korenman Sanders; Neumark, David 2000: Cohort Crowding and Youth Labor Markets: A Cross-National Analysis. In: Blanchflower; David G.; Freeman, Richard B. (Eds.): Youth Employment and Joblessness in Advanced Countries. Chicago: NBER Chicago University Press: 57-105.

Kwon, Illoong; Meyersson-Milgrom, Eva; Hwang, Seiwoon 2010: Cohort Effects in Promotions and Wages. Evidence from Sweden and the United States. In: Journal of Human Resources 45,3: 772-808.

Larsen, Klaus; Merlo, Juan 2005: Appropriate Assessment of Neighborhood Effects on Individual Health: Integrating Random and Fixed Effects in Multilevel Logistic Regression. In: Journal of Epidemiology 161,1: 81-88 [doi: 10.1093/aje/kwi017].

Larsen, Klaus; Petersen Jørgen H.; Budtz-Jørgensen, Esben; Endahl, Lars 2000: Interpreting Parameters in the Logistic Regression Model with Random Effects. In: Biometrics 56,3: 909-914 [doi: 10.1111/j.0006-341X.2000.00909.x].

Lazear, Edward R. 1979: Why Is There Mandatory Retirement? In: Journal of Political Economy 87,6: 1261-1284. 
Lee, Jim 2000: The robustness of Okun's law: Evidence from OECD countries. In: Journal of Macroeconomics 22,2: 331-356 [doi: 10.1016/S0164-0704(00)00135-X].

Macunovich, Diane J. 2009: Older Men: Pushed into Retirement by the Baby Boomers? IZA Discussion Paper No. 4652. Bonn.

Merlo, Juan et al. 2006: A Brief Conceptual Tutorial of Multilevel Analysis in Social Epidemiology: Using Measures of Clustering in Multilevel Logistic Regression to Investigate Contextual Phenomena. In: Journal of Epidemiology and Community Health 60: 290-297 [doi: 10.1136/jech.2004.023473].

Merlo, Juan et al. 2009: Individual and collective bodies: using measures of variance and association in contextual epidemiology. In: Journal of Epidemiology and Community Health 63: 1043-1048 [doi: 10.1136/jech.2009.088310].

OECD 2005: Alterung und Beschäftigungspolitik Deutschland. Organisation für wirtschaftliche Zusammenarbeit und Entwicklung. Paris: OECD Publishing [doi: 10.1787/9789264014060-de].

Okun, Arthur M. 1962: Potential GNP: Its Measurement and Significance. In: American Statistical Association: Proceedings of the Business and Economic Statistics Section of the American Statistical Association. Alexandria: 89-104.

Oreopoulos, Philip; von Wachter, Till; Heisz, Andew 2008: The Short-and Long-Term Career Effects of Graduating in a Recession: Hysteresis and Heterogeneity in the Market for College Graduates. IZA Discussion Paper No. 3578. Bonn.

Prskawetz, Alexia; Lindh, Thomas (Eds.) 2006: The Impact of Population Ageing on Innovation and Productivity Growth in Europe. Vienna Institute of Demography, Austrian Academy of Sciences. Research Report 28. Vienna.

Rabe-Hesketh, Sophia; Skrondal, Anders 2005: Multilevel and Longitudinal Modelling Using Stata. College Station, TX: Stata Press.

Ruhm, Christopher J. 1990: Bridge Jobs and Partial Retirement. In: Journal of Labor Economics 8,4: 482-501.

Schils, Trudie 2008: Early Retirement in Germany, the Netherlands, and the United Kingdom: A Longitudinal Analysis of Individual Factors and Institutional Regimes. In: European Sociological Review 24,3: 315-329 [doi: 10.1093/esr/jcn009].

Schwarze, Johannes 2003: Using Panel Data on Income Satisfaction to Estimate Equivalence Scale Elasticity. In: Review of Income and Wealth 49,3: 359-372 [doi: 10.1111/1475-4991.00092].

Shimer, Robert 2001: The Impact of Young Workers on the Aggregate Labor Market. In: The Quarterly Journal of Economics 116,3: 969-1007 [doi: 10.1162/00335530152466287].

Snijders, Tom A.B.; Bosker, Roel. J. 1999: Multilevel Analysis. An Introduction to Basic and Advanced Multilevel Modeling. London: Sage.

Snijders, Tom A.B. 2005: Power and Sample Size in Multilevel Linear Models. In: Everitt, Brian S.; Howell, David C. (Eds.): Encyclopedia of Statistics in Behavioral Science. Volume 3. Chicester: Wiley: 1570-1573 [doi: 10.1002/0470013192.bsa492].

Stenberg, Anders; Wikström, Magnus 2004: Higher Education and the Determination of Aggregate Male Employment by Age. In: Education Economics 12,1: 87-101 [doi: 10.1080/0964529042000193961].

Welch, Finis 1979: Effects of Cohort Size on Earnings: The Baby Boom Babies' Financial Bust. In: Journal of Political Economy 87,4: 65-98.

Zimmermann, Klaus F. 1991: Ageing and the Labour Market. Age Structure, Cohort Size, and Unemployment. In: Journal of Population Economics 4: 177-200. 
968 - Henriette Engelhardt, Christopher Schmidt

A German translation of this reviewed and authors' authorised original article by the Federal Institute for Population Research is available under the title "Auswirkungen des Generationenwettbewerbs und -austausches auf die späte Erwerbsbeteiligung und den Erwerbsausstieg aus einer Mehrebenenperspektive", DOI 10.12765/CPoS-2013-21de or URN urn:nbn:de:bib-cpos-201321de9, at http://www.comparativepopulationstudies.de.

Date of submission: 18.01.2012

Date of Acceptance:22.11.2012

Prof. Dr. Henriette Engelhardt, Christopher Schmidt ( $₫)$.Bamberg University, Germany.

E-Mail: henriette.engelhardt-woelfler@uni-bamberg.de,

christopher.schmidt@uni-bamberg.de

URL: http://www.uni-bamberg.de/bamberg-graduate-schools/english/bagss/people/ faculty/henriette-engelhardt-woelfler/

URL: http://www.uni-bamberg.de/bamberg-graduate-schools/english/bagss/people/ doctoral-students/associate-members/christopher-schmidt/ 


\section{Appendix}

\begin{tabular}{|c|c|c|}
\hline & $\begin{array}{l}\text { Labour market } \\
\text { participation of males } \\
\text { aged } 50-64 \text { in wave } 1\end{array}$ & $\begin{array}{c}\text { Labour market exit of } \\
\text { males aged } 50-61 \\
\text { between wave } 1 \text { and } \\
\text { wave } 2\end{array}$ \\
\hline \multirow[t]{2}{*}{ Age $53-55$} & $-0.264+$ & $1.079 * * *$ \\
\hline & $(1.828)$ & $(4.200)$ \\
\hline \multirow[t]{2}{*}{ Age $56-58$} & $-1.111 * * *$ & $1.996 * * *$ \\
\hline & (8.173) & (8.368) \\
\hline \multirow[t]{2}{*}{ Age 59-61 } & $-1.889 * * *$ & $2.641^{* * *}$ \\
\hline & $(14.230)$ & $(12.496)$ \\
\hline \multirow[t]{2}{*}{ Age $62-64$} & $-2.530 * * *$ & --- \\
\hline & $(18.618)$ & \\
\hline \multirow[t]{2}{*}{ Secondary education } & $0.219^{*}$ & -0.209 \\
\hline & (2.104) & $(1.072)$ \\
\hline \multirow[t]{2}{*}{ Tertiary education } & $0.310^{* *}$ & -0.321 \\
\hline & (2.875) & $(1.540)$ \\
\hline \multirow[t]{2}{*}{ Less than good health } & $-0.907 * * *$ & $0.326^{*}$ \\
\hline & $(10.608)$ & $(2.268)$ \\
\hline \multirow[t]{2}{*}{ Log of ppp-adjusted household income } & $0.447 * * *$ & $-0.335+$ \\
\hline & (4.682) & (1.774) \\
\hline \multirow[t]{2}{*}{ Log of household size } & $0.288^{*}$ & $-0.615^{* *}$ \\
\hline & $(2.233)$ & $(2.580)$ \\
\hline \multirow[t]{2}{*}{ Partner employed } & $2.251 * * *$ & $-0.407^{*}$ \\
\hline & (18.547) & (2.298) \\
\hline \multirow[t]{2}{*}{ No partner } & $0.648 * * *$ & $-1.072^{* * *}$ \\
\hline & $(5.526)$ & $(4.469)$ \\
\hline \multirow[t]{2}{*}{ Self-employed } & & $-0.767 * * *$ \\
\hline & & (3.463) \\
\hline \multirow[t]{2}{*}{ Unemployed } & & -0.010 \\
\hline & & $(0.054)$ \\
\hline \multirow[t]{2}{*}{ Tertiary sector } & & -0.181 \\
\hline & & $(1.025)$ \\
\hline \multirow[t]{2}{*}{ Public sector } & & 0.275 \\
\hline & & $(1.471)$ \\
\hline \multirow[t]{2}{*}{ 25-199 199 employees } & & -0.106 \\
\hline & & $(0.556)$ \\
\hline \multirow[t]{2}{*}{$200+199$ employees } & & 0.247 \\
\hline & & (1.379) \\
\hline \multirow[t]{2}{*}{ Satisfied with job } & & $-0.555^{* *}$ \\
\hline & & (2.965) \\
\hline
\end{tabular}


970 - Henriette Engelhardt, Christopher Schmidt

Continuation Appendix

\begin{tabular}{lcc}
\hline & $\begin{array}{c}\text { Labour market } \\
\text { participation of males } \\
\text { aged 50-64 in wave 1 }\end{array}$ & $\begin{array}{c}\text { Labour market exit of } \\
\text { males aged 50-61 } \\
\text { between wave 1 and } \\
\text { wave 2 }\end{array}$ \\
\hline Between-country-variance & $0.283^{* *}$ & $0.331^{*}$ \\
Intra-class correlation (ICC) & $(2.725)$ & $(2.203)$ \\
Median odds ratio (MOR) & 0.079 & 0.092 \\
B/C & 1.661 & 1.732 \\
Observations & $3,826.1$ & $2,123.8$ \\
\hline
\end{tabular}

Notes: Standardised beta coefficients; Absolute t-statistics in parentheses; $+p<0.10$, ${ }^{*} \mathrm{p}<0.05,{ }^{* *} \mathrm{p}<0.01,{ }^{* * *} \mathrm{p}<0.001$

Source: SHARE, Version 2.5.0; own calculations 


\section{Comparative Population Studies - Zeitschrift für Bevölkerungswissenschaft}

wWw.comparativepopulationstudies.de

ISSN: 1869-8980 (Print) - 1869-8999 (Internet)

Published by / Herausgegeben von

Prof. Dr. Norbert F. Schneider

Federal Institute for Population Research

D-65180 Wiesbaden / Germany

Managing Editor /

Verantwortlicher Redakteur

Frank Swiaczny

Assistant Managing Editor /

Stellvertretende Redakteurin

Katrin Schiefer

Language \& Copy Editor (English) /

Lektorat \& Übersetzungen (englisch)

Amelie Franke

Copy Editor (German) /

Lektorat (deutsch)

Dr. Evelyn Grünheid

\section{Layout / Satz}

Beatriz Feiler-Fuchs

E-mail: cpos@bib.bund.de

\author{
Scientific Advisory Board / \\ Wissenschaftlicher Beirat \\ Jürgen Dorbritz (Wiesbaden) \\ Paul Gans (Mannheim) \\ Johannes Huinink (Bremen) \\ Marc Luy (Wien) \\ Clara H. Mulder (Groningen) \\ Notburga Ott (Bochum) \\ Peter Preisendörfer (Mainz)
}

\section{Board of Reviewers / Gutachterbeirat} Martin Abraham (Erlangen)

Laura Bernardi (Lausanne) Hansjörg Bucher (Bonn)

Claudia Diehl (Konstanz)

Andreas Diekmann (Zürich)

Gabriele Doblhammer-Reiter (Rostock)

Henriette Engelhardt-Wölfler (Bamberg)

E.-Jürgen Flöthmann (Bielefeld)

Alexia Fürnkranz-Prskawetz (Wien)

Beat Fux (Zürich)

Joshua Goldstein (Rostock)

Karsten Hank (Köln)

Sonja Haug (Regensburg)

Franz-Josef Kemper (Berlin) †

Michaela Kreyenfeld (Rostock)

Aart C. Liefbroer (Den Haag)

Kurt Lüscher (Konstanz)

Dimiter Philipov (Wien)

Tomáš Sobotka (Wien)

Heike Trappe (Rostock) 